Jupiter and Saturn. The apparatus and experimental methods used, as well as the numerous obstacles which were encountered in the conduct of the work, were fully described: The numerous data recorded during the course of experiments were presented. The subject was illustrated by lantern slides. In the brief discussion which followed the presentation of the paper, Messrs. Levy, Henderson, and Bond participated.

A rising vote of thanks was extended to the speaker. Adjourned.

R. B. OWENS, Secretary.

\title{
REPORT OF THE BOARD OF MANAGERS FOR THE YEAR ENDING SEPTEMBER 30, 1913, WITH APPEN- DICES EMBRACING THE ANNUAL REPORTS OF THE VARIOUS COMMITTEES AND SECTIONS.
}

To the Members of The Franklin Institute:

Your Board of Managers formally present herewith the reports of the standing committees upon the operations of the past year. These reports have been printed, and a copy will be sent to each member of the Institute. The Board hope that you will come from the reading of these reports satisfied that the work of the Institute has been conducted with industry and intelligence by those to whom you have entrusted it.

The Committee on Instruction, Mr. Paul, Chairman, report an increase in the enrolment of students and in the number of graduates for this, the ninetieth consecutive year of the school's activity. The Institute has recently greatly improved its school facilities, and is rewarded therefor by a most gratifying increase in the student roll. The registration of students for the winter term has steadily increased from 173 , in 1909 , to 306 , in 1913 , and the number of graduates has increased in practically the same proportion. We have now as many students on our rolls as we can properly care for in the space that we are able to devote to this purpose. Our effort of late has not been to increase the attendance at our schools, but to improve the quality of the service that we render to the individuals and to the community through that branch of our work.

The report of the Committee on Elections and Resignations of Members, Mr. Eglin, Chairman, shows a gratifying increase in the membership-now numbering I395. We have elected, during the past year, 292 members, which is the largest enrolment for any year since the present rate of dues was established. We have increased nearly so per cent. in membership in the past five years. The record of resignation of nembers shows that the resignations are much less, in proportion to the total enrolment, than we had, unfortunately, become accustomed to expect. This is one of the most convincing and gratifying evidences of an increased interest in the work the Institute is doing for the public good, as well as an increased appreciation of what the Institute does for the individual member. 
We learn from the report of the Library Committee, Mr. Levy, Chairman, that there have been 3306 additions to the library during the past year, which is about to per cent. more than in the previous year, and 50 per cent. more than the increases in rgog. The library is used more and more largely from year to year. The pressing demands of the library to-day are for increased space and more convenient location.

The report of the Committee on Publications, Mr. Levy, Chairman, while interesting, calls for no special comment. I desire, however, to again call your attention to the JourNal. Within the past few years there has been created a board of associate editors, comprising twenty men, of international reputation for scientific work. This is an added, and the most certain attainable, assurance of value and accuracy in our senior publication. The size of the JoURnal, during the last five years, has been increased about 25 per cent. Its standing in the scientific world, always notable, has been fully maintained.

The Year Book of the Institute, brought out by the Committee on Publications, is a worthy publication, setting out the activities of the Institute, and containing historical notes, the programme of lectures, the charter and by-laws, and a list of the membership.

The Committee on Meetings, Mr. Rogers, Chairman, report monthly meetings from October to May, inclusive, at many of which the capacity of the Hall was overtaxed. The subjects treated covered a wide field of scientific and engineering activity, as will be seen by reference to the Journal for the past year.

The Committee on Sectional Arrangements, Mr. Day, Chairman, report an even better attendance during the past year than in previous years. The committee report sixteen meetings during the year, each with a lecture from some man of acknowledged authority in his line of work. The high standard for these meetings, set for us by our predecessors, is being fully maintained by the members of the Sections and of your Committee on Sectional Arrangements.

The report of the Committee on Exhibitions, Mr. Birkinbine, Chairman, contains no present recommendation, but suggests the possibility of an exhibition in the near future.

The Committee on Museums, Professor Outerbridge, Chairman, presents an interesting report, covering, in the main, a list of gifts received during the year and placed in charge of this committee. Some of these gifts are of great historic interest. The Board respectfully suggest that you, members of the Institute, do not sufficiently appreciate the number and interest of the articles in charge of the Committee on Museums. They are now all available for convenient inspection.

The report of the Committee on Science and the Arts, Mr. Crisfield, Chairman, shows great activity. It contains certain recommendations that will be considered by the Board and by the committee for the year igr4. The committee report the disposition of twenty-seven cases during the year, with seventeen awards made. The report shows the very broad field covered by the committee's efforts; and in the list of awards made will be found the names of men among the most distinguished in their respective branches of scientific work. 
The report of the Finance Committee, Mr. Forstall, Chairman, shows that for the year covered by the report the Institute had an income applicable

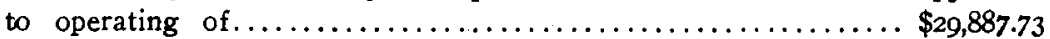
that the operating costs were $\ldots \ldots \ldots \ldots \ldots \ldots \ldots \ldots \ldots \ldots \ldots, 34,158.42$ making a deficit for the year's operation of $\ldots \ldots \ldots \ldots \ldots \ldots . \$ 4,270.69$

Our financial condition has improved of late years. We have some reason to believe that our days of deficits will soon be past.

In this connection we make the following memorandum of endowments received during the past three years :

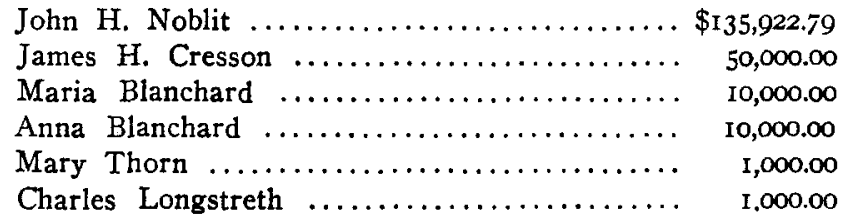

Through the generosity of $\mathrm{Mr}$. Samuel Insull, of Chicago, we are able to provide an additional and very valuable gold medal, to be known as the Franklin Medal, and to be awarded for general scientific achievement, leaving the Elliott Cresson Gold Medal to be awarded for specific achievement in science. Your Board think this medal makes complete our list of awards, enabling The Franklin Institute to satisfactorily evidence its approval of notable work for the good of mankind in any part of the broad field of science.

Since our last report to you the widow of our good and lamented friend and one-time secretary, Dr. Wm. H. Wahl, has laid down the burden of her mortality. This fact is worthy of record, both because of the distinguished services that Dr. Wahl rendered to the Institute and because of the fact that, under his will, his estate was to descend to the Institute, upon the death of his wife-conditioned on the Institute's raising a sum equal to the value of the estate. The present value of the estate is about $\$ 85,000$. It is incumbent upon the membership to secure that this munificence be not lost to us. This award being secured, there will be no further anxiety as to the financial support of the work the Institute is doing for the good of the citizen and of the State.

Your Board have satisfaction in reporting to you the purchase by your Franklin Fund and Building Committee, Mr. Howson, Chairman, of 23,320 square feet of land and the eight residences thereon, fronting Logan Square and the route of the boulevard. The land lies on the southeast corner of Race and Nineteenth streets. The Parkway frontage is r Io feet. Among our near neighbors, when we have secured the necessary further funds and erected a building upon this incomparable site, will be the Cathedral, Wills Eye and Ear Hospital, the Academy of Natural Sciences, and the great and noble new Public Library.

Your Board regard the acquisition of this valuable and improving real estate by the Institute as a notable achievement for the cause of the 
scientific advancement of the mechanic arts in the State of Pennsylvania, and congratulate you upon it.

While we look with hope to the day when a new building, larger than this in which we now gather and on the more convenient site, will enable us to better serve the citizen and the State, we will not abate our efforts in the interim to carry on the work of The Franklin Institute in this beautiful and historic building in a manner as nearly may be worthy of the confidence you have shown in us, and of the standards set by the able and devoted men who have preceded us.

Walton Clark,

President.

\section{REPORT OF THE COMMITTEE ON INSTRUCTION.}

\section{To the Board of Managers:}

The Committee on Instruction has been much gratified by the favorable showing made by The Franklin Institute School of Mechanic Arts during the past school year and by the marked increased interest shown by the members of the Institute in the course of Popular Lectures.

The School, now in the goth year of its existence, opened its winter course in September, 1913, with an enrolment of 306 students, an increase of 20 over the corresponding term of the preceding year. The plan of instruction was similar to that of the previous year, the work of the School being divided into four departments, Drawing, Mathematics, Mechanics and Naval Architecture.

The faculty for the year consisted of:

Professor William H. Thorne, Director and in charge of the Department of Drawing.

Professor William E. Bullock, Assistant Director and in charge of the Department of Mechanics.

Professor H. P. Tyson, in charge of the Department of Mathematics.

Professor H. C. Towle, in charge of the Department of Naval Architecture.

Professor Thorne was ably assisted in his department by Professor Clement Remington, in charge of Architectural and Freehand Drawing, and by Messrs. F. H. Lobb, I. P. Pedrick, C. Rommel and W. W. Twining, Assistants in Mechanical Drawing.

Professor Bullock had in Messrs. Bark and Wheatley very competent assistants.

Throughout the year the classes were well attended and the standard of work was exceptionally good. Seven visits were made on Saturday afternoons during the season to some of the most prominent industrial plants, and also special invitations were given to the students to attend such of the Institute lectures as were of direct interest to them.

The visits made were as follows:

The Ogontz Power Plant of the Phila. Rapid Transit Co.,

The Belmont Pumping Station,

Vor. CLXXVII, No. 1058-17 